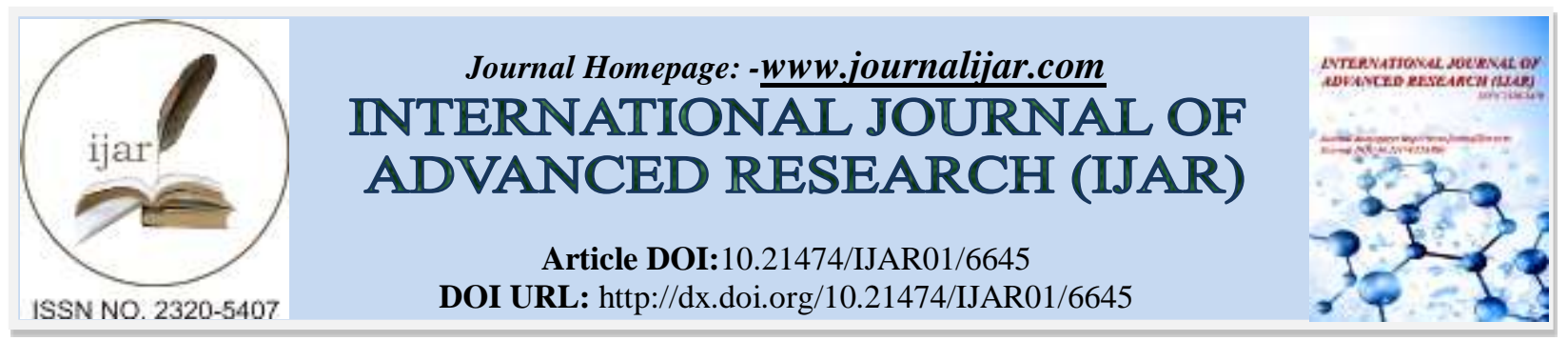

RESEARCH ARTICLE

\title{
EFFECTIVENESS OF ROLE PLAY MODEL IN TEACHING HINDI AT SECONDARY LEVEL IN KERALA.
}

Dr. Pradeep Kumar S. L.

Associate Professor N.S.S. Training College, Changanacherry, Kerala, South India.

\section{Manuscript Info}

Manuscript History

Received: 02 January 2018

Final Accepted: 04 February 2018

Published: March 2018

\begin{abstract}
This study was undertaken to test the effectiveness of Role play model in the achievement of $8^{\text {th }}$ standard students in Hindi when compared to the achievement of their counterparts who were exposed to prevailing method of instruction adopted in the schools of Kerala. The sample consists of 144 students out of which 72 students were included in the Experimental group and the rest in the Control group. Pre-test was conducted and Experimental group was exposed to Role play model and Control group to the prevailing method. The result of the study shows that Role play model is much effective than the traditional method as far as the achievement of students is concerned. The result of the study also shows that when compared to the students in the government school, Role play model was found to be much beneficial to the students of aided schools.
\end{abstract}

Copy Right, IJAR, 2018,. All rights reserved.

\section{Introduction:-}

Role play is a teaching strategy that comes under the social family of models (Joyce and Weil, 2000). Models, that comes under this category emphasize the social nature of learning, and view cooperative behaviour as stimulating students both socially and intellectually. It is a strategy derived from socio drama that may be used to help students understand the more subtle aspects of literature and other areas of knowledge. Role play as a teaching strategy offers several advantages for both teachers and students. When role play is brought to practice in the classroom, student interest is fortified in the subject matter, thus generating interest in the subject matter. The use of role playing emphasizes personal concerns, problems, behaviour and active participation. Role play improves interpersonal skills and enhances communication.

Role play facilitates learning across many areas of curriculum content, it involves manipulating knowledge in exciting ways and helps make abstract problems more concrete, facilitates expression of attitudes and feelings. Role play develops sympathetic understandings and motivates learners to apply their knowledge in solving different problems. It demonstrates a practical integration of knowledge, skills, abilities and promotes lifelong learning. Role play encourages students while participating in the activity, to reflect their knowledge regarding a particular subject area. Thus, Role play is an excellent teaching strategy for receiving or reflecting the learning content at the end of the teaching-learning activity. Students are directed to use appropriate concepts and arguments as demanded by their role. Along with the role change, naturally concepts and arguments also change. Such twists are very helpful in developing divergent and reflective thinking skills in students. 
Role play as a teaching model was brought to contemporary prominence in large part through Fannie Shaftel and George Shaftel (1970). Fannie Shaftel described role play for development of interpersonal skills through dramatizations of 'life-situations'. It is an effective teaching model for influencing learner attitudes and for bringing about change in group interactions and relationships. New insights and attitudes gained from role play are easily transferable to other situations also. It is an effective teaching model for affecting individual attitudes and for bringing about Stevens, Rachel's (2015) change in group interactions and relationships. study shows that large majority of students found Role play beneficial. According to Lu, Fang - Chang (2016) Role play can facilitate student's English vocabulary. According to them Role play is also effective in promoting student's active participation, especially on external expectations and social contact perspectives. Julins, Kemboi, Osman, Ahmed's (2015) study shows that Role play is the most appropriate technique to improve performance of students in English language. Chin, Joseph C; Martin, Akilah R (2015) found that Role play focus on change in the views of students in a real- world context and include a problem-solving approach that demands a solution. It is evident from studies conducted all around the globe that along with academic benefits Role play is also helpful in developing social adjustment, co-operation, behaviour consistency and self- concept in students.

Objective of the Study:-

The objective of the study is to find out the effectiveness of Role play Model in teaching Hindi at Secondary level in Kerala

Hypothesis of the Study:-

The academic achievement of students exposed to Role play model will be significantly higher than that of pupils taught by prevailing method of instruction.

\section{Methodology:-}

The present study made use of the pre-test post-test non-equivalent group experimental design for realizing the objective. This design is often used in class room experiments when experimental and control groups are such naturally assembled groups as intact classes (Best \& Khan, 1999). The independent variables involved in the study are Role play model and prevailing method of teaching, while achievement of students in Hindi was taken as dependent variable.

\section{Sample:-}

A total number of 144 Secondary school students of standard 8, selected randomly were taken as Sample.

\section{Tool used:-}

Lesson manuals prepared by the investigator for Role play and prevailing method of teaching Hindi.

\section{Result and Discussion:-}

To find out the effectiveness of the select Role play Model over the prevailing classroom transaction mode in enhancing academic achievement among the students at Secondary school level, the pre-test and post-test scores of the Role play Model group and Control groups were analysed using appropriate statistical techniques as shown below:

Comparison of Pre-test scores of Role Play Model Group and the Control Group on Academic achievement As an initial step to assess the degree to which the select curriculum transaction strategy namely Role play Model could improve academic achievement of students over the prevailing Activity oriented approach, the mean and standard deviation of the pre-test scores of students in each group were computed and the critical ratio was found out. The results of the test of significance are presented in Table 1.

Table 1:- The results of Test of Significance of the Difference between the Means of Pre-test Scores of Role Play Model Group and the Control Group on Academic achievement

\begin{tabular}{|c|c|c|c|c|c|}
\hline Pre-test & & & & & \\
\hline Groups & $\mathrm{N}$ & Mean & $\mathrm{SD}$ & C.R. & Level of Sig. \\
\hline Role Play & 72 & 5.65 & 2.97 & 0.572 & 0.568 \\
\hline Control & 72 & 5.38 & 2.85 & & \\
\hline
\end{tabular}


Table 1 shows the test of significance of difference in mean pre-test scores of academic achievement of secondary students taught through the experimental strategy- Role play and Control Group by using ' $t$ ' test. The mean scores of experimental and control group are 5.65 and 5.38 respectively. The standard deviation of the Experimental group is 2.97 and that of the Control group is 2.85. The level of significance of $t$-test obtained is greater than 0.05 . Hence the difference in the mean pre-test scores of academic achievement between the students taught through Role play Model and the prevailing Activity modes of transaction in the schools is not significant at both 0.01 and 0.05 levels, indicating that the two groups are equitable in their initial level of academic performance.

Comparison of Post-test scores of Role Play Model group and the Control group on Academic achievement

In order to find out whether there existed significant difference between the post- test scores of students in the Control group and the Role play Model group on academic achievement, the Mean and Standard deviation of the post test scores of students in each group was calculated and critical ratio was found out. The details are presented in Table 2

Table 2:- The Results of Test of Significance of the Difference between the Means of Post-test Scores of Role Play Model Group and the Control Group on Academic achievement

\begin{tabular}{|c|c|c|c|c|c|}
\hline \multicolumn{6}{|l|}{ Post-test } \\
\hline Groups & $\mathrm{N}$ & Mean & SD & C.R. & Level of Sig. \\
\hline Role Play & 72 & 12.76 & 3.78 & 4.310 & 0.000 \\
\hline Control & 72 & 9.83 & 4.36 & & \\
\hline
\end{tabular}

Table 2 shows that the mean scores of the experimental and control groups are 12.76 and 9.83 respectively. The standard deviation of the Role play group is 3.78 and that of the Activity oriented group is 4.36 . The level of significance is less than 0.05 . This shows that, the students who were exposed to the select strategy, namely Role play Model, made significant improvement in their level of academic achievement with that of their counterparts in the Control group exposed to the prevailing method of instruction in the schools of Kerala.

B .Comparison of mean Pre-test scores of Role Play Model group based on type of Institution towards Academic achievement

The mean and standard deviation of the Pre-test scores of Aided and Government Secondary school students belong to the Role play group were computed to find out initial difference in their academic performance. Table 3 shows the details in this regard.

Table 3:- The Results of the Test of Significance of Pre-test Scores of students in the Role Play Model Group based on Type of Institution towards Academic achievement

\begin{tabular}{|c|c|c|c|c|c|}
\hline Pre-test & & & & & \\
\hline Groups & $\mathrm{N}$ & Mean & SD & C.R. & Level of Sig. \\
\hline Aided & 36 & 6.06 & 3.46 & 1.152 & 0.253 \\
\hline Government & 36 & 5.25 & 2.38 & & \\
\hline
\end{tabular}

Table 3 shows the mean pre-test scores of the groups of student given experimental treatment Role play, from both aided as well as Government schools. The table shows that the mean Pre-test scores of groups selected from Aided schools is 6.06 and Government schools 5.25. Since the level of significance 0.253 is greater than the table value, it becomes clear that there exist no significant difference between the pre-test scores of students who were provided with experimental treatment 'Role play' from Aided and Government schools.

Comparison of mean Post-test scores of Role Play Model group based on type of Institution towards Academic achievement

The mean post-test scores of the sub sample based on type of institution in the Role play Model group towards academic achievement was calculated in order to find out whether they differed in their academic achievement when exposed to the Role play Model. Table 4 shows the details of this aspect. 
Table 4:- The Results of the Test of Significance of Post-test Scores of students in the Role Play Model Group based on Type of Institution towards Academic achievement

\begin{tabular}{|c|c|c|c|c|c|}
\hline Post-test & & & & & \\
\hline Groups & $\mathrm{N}$ & Mean & SD & C.R. & Level of Sig. \\
\hline Aided & 36 & 13.94 & 3.57 & 2.774 & 0.007 \\
\hline Government & 36 & 11.58 & 3.65 & & \\
\hline
\end{tabular}

Table 4 shows the post-test scores of the experimental group 'Role play' from both Aided and Government school. The analysis shows that, the sub groups based on type of institution differ significantly in their Post test scores, as the level of significance is greater than the table value 0.05 . So it can be inferred that Role play Model is much beneficial for Aided school students than those from Government school.

\section{Conclusion:-}

The hypothesis of the study "The Academic achievement of students exposed to Role play Model will be significantly higher than that of pupils taught by prevailing method of instruction" was accepted. The mean scores of the experimental and control groups are 12.76 and 9.83 respectively. The standard deviation of the Role play group is 3.78 and that of the Activity oriented group is 4.36 . The level of significance is less than 0.05 . This shows that, the students who were exposed to the select strategy, namely Role play Model, made significant improvement in their level of academic achievement with that of their counterparts in the Control group exposed to the prevailing method of instruction in the schools of Kerala. The study proves that Role play Model of instruction is very effective than the conventional class room methods in ensuring high educational outcomes in a psychological way.

The Results of the Test of significance of Post-test scores of students in the Role play Model group based on type of institution towards academic achievement shows that, the sub groups based on type of institution differ significantly in their Post test scores, as the level of significance is greater than the table value 0.05 . So it can be inferred that Role play Model is much beneficial for Aided school students than those from Government school. This demands high attention from the part of the teachers and other stakeholders of Government schools.

\section{References:-}

1. Best, J.W. \& Khan; J.V. (1999). Research in Education ( $7^{\text {th }}$ ed.). New Delhi: Prentice Hall.

2. Bruce Joyce, Marsha Weil (1972). Models of Teaching. Englewood Cliffs, N. J: Prentice Hall.

3. Chin, Joseph C; Martin, Akilah R (2015) Role play simulations as a Transformative Methodology in Environmental Education ; Journal of Transformative Education, v13 n I p 85-102.

4. Donahue, M, \& Parsons, A.H. (1982). The Use of Role Play to Overcome Cultural fatigue. TESOL Quarterly, 16(3), 359-365.

5. Fannie R Shaftel, George Shaftel (1982). Role Playing in the Curriculum: Englewood Cliffs, N.J: Prentice Hall.

6. Julins, Kemboi, Osman, Ahmed's (2015). Journal of Education and Pratice, v 6 n 5 19-124.

7. Lu, Fang - Chang (2016). Role Play Game - Enhanced English for a specific purpose. Journal of Education Technology \& Society v19 n2 p 367-377.

8. Shaftel, F.R (1970). Role Playing: An Approach to meaningful social learning. Social education, 34 (5), 556559.

9. Stevens, Rachel's (2015). Role Play and Student Engagement: Reflections from the Class room. Teaching in Higher Education, v 2 n 5 p 481-492 